\title{
Effects of dietary sepiolite and mannanoligosaccharide supplementation on the performance, egg quality, blood and digestion characteristics of laying hens receiving aflatoxin in their feed
}

\author{
Cengizhan MIZRAK ${ }^{1}$, Engin YENICE ${ }^{1}$, Züleyha KAHRAMAN ${ }^{1}$, Muhammet TUNCA ${ }^{1}$, \\ Uğur YILDIRIM ${ }^{1}$, Necmettin CEYLAN ${ }^{2}$
}

${ }^{1}$ Poultry Research Station, Ankara; ${ }^{2}$ University of Ankara, Faculty of Agriculture, Department of Animal Sciences, Ankara, Turkey.

Summary: In this experiment, sepiolite (\% 1.5 and \% 3) and mannanoligosaccharide (MOS, \% 0.1 ) were fed to layers each receiving $120 \mathrm{ppb}$ aflatoxin, and were compared to control $(\mathrm{K})$ and negative control (NK) groups. The experiment began at $26 \mathrm{wk}$ of hen age and continued for $12 \mathrm{wk}$. Each of the five dietary treatments was randomly assigned to six replicates each included six hens. There were no significant differences ( $p>0.05)$ in livability, live weight change, egg weight and feed intake between the groups. NK had worse feed conversion ratio than control $(\mathrm{P}<0.05)$. The addition of $\% 1.5$ sepiolite resulted in an increase in egg production and egg mass in comparison to NK and MOS groups, and in an increase in feed efficiency $(\mathrm{P}<0.05)$. There were no differences between the groups in parameters characterizing egg quality, namely, in the ratio of cracked-broken eggs, albumen height, haugh unit, shape index, shell thickness, and shell resistance, moreover, in the colour (RYCF), shine (L) and yellowness (b) of egg yolk ( $\mathrm{P}>0.05$ ). Aflatoxin was not detected in eggs obtained from any of the groups. The $\mathrm{pH}$ of faeces of hens in the NK group was higher than that of birds in the $\mathrm{K}$ and the $3 \%$ sepiolite-treated groups $(\mathrm{p}<0.05)$. The proportion of dry matter of the feces was the lowest in the NK group, nevertheless, the difference between the groups was not significant ( $p>0.05)$. The addition of MOS and sepiolite to the feed reduced the degree of digestion of aflatoxin by \% 6-12. As a result, sepiolite supplementation to laying hen diets containing aflatoxins can be concluded that had the beneficial effects on hen performance.

Key words: Aflatoxin, mannanoligosaccharide, performance, sepiolite, laying hen.

\section{Aflatoksin içeren yumurta tavuğu yemlerine sepiolit ve mannanoligosakkarit ilavesinin performans, yumurta kalitesi, kan ve sindirim özelliklerine etkileri}

Özet: $\mathrm{Bu}$ araştırmada, ortalama $120 \mathrm{ppb}$ toplam aflatoksin içeren yumurta tavuğu yemlerine sepiolit (\% 1.5 ve 3 ) ve mannanoligosakkarit (MOS, \% 0.1) ilavesi yapılmış, bu gruplar, kontrol (K) ve negatif kontrol (NK) grupları ile karşılaştırılmıştır. Deneme tavuklar 26 haftalık yaşta iken başlamış ve 12 hafta devam etmiştir. 5 deneme grubunun her biri 6 tekerrürden ve her tekerrür de rastgele atılan 6 tavuktan oluşmuştur. Gruplar arasında yaşama gücü, canlı ağırlık değişimi, yumurta ağırlığ ve yem tüketimi gibi performans değerleri bakımından önemli farklılıklar gözlenmemiştir ( $\mathrm{P}>0.05)$. NK grubu, kontrol grubuna göre yemi daha kötü değerlendirmiştir $(\mathrm{P}<0.05)$. Yeme \% 1.5 düzeyinde sepiolit ilavesi yumurta verimi ve kütlesini NK ve MOS gruplarına göre önemli düzeyde artırmış, yem değerlendirmeyi iyileştirmiştir $(\mathrm{P}<0.05)$. Yumurta kalitesini belirleyen özelliklerden kırık-çatlak yumurta oranı, ak yüksekliği, haugh birimi, şekil indeksi, kabuk kalınlığı ve mukavemeti, yumurta sarısı RYCF, L, a ve b renk değerleri bakımından gruplar arasında farklılık bulunmamıştır ( $\mathrm{P}>0.05)$. Hiçbir grubun yumurtasında aflatoksin tespit edilmemiştir. NK grubundaki tavukların dışkı pH'ının K ve \% 3 sepiolit ilaveli gruplara göre yüksek olduğu belirlenmiştir $(\mathrm{P}<0.05)$. Dışk1 kuru madde oranı bakımından gruplar arasında önemli farklılıklar belirlenmemesine rağmen $(\mathrm{P}>0.05)$, NK grubunun diğer gruplardan daha düşük dışkı kuru maddesine sahip olduğu görülmektedir. Yeme MOS ve sepiolit ilaveleri aflatoksinin sindirim derecesini \% 612 oranında azaltmıştır. Sonuç olarak, aflatoksin içeren yumurta tavuğu yemlerine sepiolit ilavesinin tavukların performansı üzerine faydalı etkilerinin olabileceği söylenebilir.

Anahtar sözcükler: Aflatoksin, mannanoligosakkarit, performans, sepiolit, yumurta tavuğu.

\section{Introduction}

The process of harvest and storage of plants used for feed, and the steps of feed production (silaging, transport, cooling, etc.), are all potential sources of microbial contamination. Consumption of feed contaminated either with microorganisms or their toxins is a major problem for the feed industry, animal growers and food producers as it causes considerable losses (6). In cases when prevention of microbial contamination had not been carried out and the release of toxins had not been 
prevented, the removing of toxins from the feed or the elimination of their poisonous effect is of great economic importance. In recent years, in particular, effective results were seen with the adding of organic and inorganic additives to feeds containing toxins $(11,18,22)$. Binding to them, these additives form compounds with the toxins thus preventing their absorption from the intestines (9, $15)$.

One of the inorganic materials used for such purpose is the natural mineral, sepiolite, a hydrous magnesium silicate belonging to the layer silicate (phyllosilicate) family. As a consequence of its molecular structure, sepiolite has high adsorption capacity. Because its fibrous character, sepiolite can be in the form of nano particles in water solutions or in other appropriate environments. This property, too, makes it an excellent adsorbent, rheological agent, drug-carrier substance and catalyst (19). Due to its magnesium ion in the octahedral layer, sepiolite is known to be a relatively good ion exchanger. It facilitates $\mathrm{Mg}$ ion discharge, especially at low $\mathrm{pH}$ values. In accordance with the above, it had been reported that, in the case of sepiolite from Turkish sources, $\mathrm{Mg}$ transfer to a water solution at neutral $\mathrm{pH}$ (approximately 8.5 ) is $10^{-4} \mathrm{~mol} / \mathrm{l}$, increasing to $10^{-2}$ at $\mathrm{pH}=3$ (10).

The use of sepiolite in animal nutrition is based on its surface makeup (structure), and its cation-transfer and ammonium-bindig properties. In addition, it had been shown to increase carcass quality, have positive effect on performance by slowing the passing of feed through the digestive system. Thus it ensues a better consistency of the feces which, in return, positively affects the environment and house hygine control (7).

Lately, biological products are also widely used for disposing toxins in feeds. Some bacteria species (Lactobasille) and Saccharomyces cerevisiae type yeasts were investigated for this purpose, and good results were obtained (4). Similarly to this yeast, which can directly be added to the feed, glucomannan, obtainable from the cell wall of yeast, or its esterified forms (mannanoligosaccharide (MOS)) can also be used.

The objective of this study was to observe the possible adverse effects of AF (120 ppb) on performance, egg quality and blood and digestion characteristics of laying hens, and to evaluate the possible beneficial effects of dietary sepiolite (1.5 and $3 \%)$ and MOS $(0.1 \%)$ as a toxin-binder.

\section{Materials and Methods}

Animals: The experiment was carried out on Barred Rock layers in the breeding sheds of the Poultry Research Institute, Ankara, in 2010. Prior to the experiment, hens were given standard layers' diet for one week. During this period, egg production and egg weight was monitored and 180 hens of similar body weight and egg production were selected. The experiment began at $26 \mathrm{wk}$ of hen age and continued for $12 \mathrm{wk}$. Each of the five dietary treatments was randomly assigned to six replicates each included six hens. Cages were in threestorey rows, $25 \times 47 \mathrm{~cm}$ in size, with manure band. The experiment during which feed and water was supplied $a d$ libitum. Chicken houses were environmentally fullcontrolled with 14 hours lighting.

Table 1. Experimental design and aflatoxin composition of diets. Tablo 1. Deneme deseni ve karma yemlerin aflatoksin içerikleri.

\begin{tabular}{lcccc}
\hline $\begin{array}{l}\text { Experimental } \\
\text { groups }\end{array}$ & $\begin{array}{c}\text { Sepiolite } \\
(\%)\end{array}$ & $\begin{array}{c}\text { MOS } \\
(\%)\end{array}$ & $\begin{array}{c}\text { Aflatoksin } \\
\text { B } 1\end{array}$ & $\begin{array}{c}\text { Total aflatoxin } \\
(\mathrm{B} 1+\mathrm{B} 2+\mathrm{G} 1+\mathrm{G} 2) \\
(\mathrm{ppb})\end{array}$ \\
\hline $\begin{array}{l}\text { Control } \\
\begin{array}{l}\text { Negative } \\
\text { control }\end{array}\end{array}$ & 0 & 0 & 2.0 & 2.0 \\
$\%$ 1.5 Sepiolite & 1.5 & 0 & 106.8 & 118.3 \\
$\%$ 3 Sepiolite & 3 & 0 & 106.5 & 119.6 \\
$\begin{array}{l}\text { Mannan- } \\
\text { oligosaccharide }\end{array}$ & 0 & 0.1 & 105.3 & 120.5 \\
\hline
\end{tabular}

Table 2. Characteristics of sepiolite in this experiment. Tablo 2. Araştırmada kullanılan sepiolitin özellikleri.

\begin{tabular}{lclc}
\hline \multicolumn{3}{c}{$\begin{array}{c}\text { Chemical } \\
\text { composition, \% }\end{array}$} & \multicolumn{1}{c}{ Physical characteristics } \\
\hline $\mathrm{SiO}_{2}$ & 37.42 & Bulk density & $770 \pm 20 \mathrm{~g} / \mathrm{lt}$ \\
$\mathrm{AI}_{2} \mathrm{O}_{3}$ & 1.45 & $\mathrm{NH}_{3}$ absorption efficiency, \% & 96.8 \\
$\mathrm{Fe}_{2} \mathrm{O}_{3}$ & 0.76 & Humidity, \% & $12 \pm 2$ \\
$\mathrm{MnO}$ & 0.007 & Sepiolite ratio, \% & 40 \\
$\mathrm{MgO}$ & 23.27 & & \\
$\mathrm{CaO}$ & 13.21 & & \\
$\mathrm{~K}_{2} \mathrm{O}$ & 0.23 & & \\
$\mathrm{TiO}_{2}$ & 0.09 & & \\
$\mathrm{LOI}$ & 24.94 & & \\
\hline
\end{tabular}

Feed: Sepiolite (\% 1.5 and 3 ) and mannanoligosaccharide (MOS, \% 0.1) were supplemented to the feed of hens receiving $120 \mathrm{ppb}$ aflatoxin, and they were compared to control (K) and negative control (NK) groups (Table 1). Mouldy corn was mixed to the feed in order to increase the amount of aflatoxin. For this purpose, corn of high aflatoxin content (100 ppb) was purchased and crushed coarsely. The corn was moistened and treated with Aspergillus flavus, aflatoxin B1 and B2, and kept at humidity of $80 \%$ in a room of $30-35{ }^{\circ} \mathrm{C}$ temperature for 15 days. By the end of this period, aflatoxin level in the corn had inreased to $200 \mathrm{ppb}$. The mouldy corn was then mixed to the feed in a proportion of $60 \%$. Diets were analysed (AOAC International, 2003) for aflatoxin $\mathrm{B} 1$ and total aflatoxin $(\mathrm{B} 1+\mathrm{B} 2+\mathrm{G} 1+\mathrm{G} 2)$ composition (Table 1). Sepiolite (Anadolu Endüstri Mineralleri San. Tic. A.Ş, İstanbul) and mannanoligosaccharide (Bil-Yem A.Ş, Ankara) used in the experiment were provided from private companies and the characteristics of this sepiolite was given Table 2 . 
Table 3. Diet composition and chemical components.

Tablo 3. Karma yemler ve kimyasal bileşimleri.

\begin{tabular}{|c|c|c|c|c|c|}
\hline Diet composition & $\mathrm{K}$ & NK & S1 & S2 & MOS \\
\hline Corn & 60 & 60 & 60 & 60 & 60 \\
\hline Wheat & 7.94 & 6.4 & 3.06 & - & 6.13 \\
\hline Soybean meal & 20.03 & 19.07 & 17.95 & 20.63 & 19.14 \\
\hline Full fat soya & - & 2.5 & 5.39 & 3.02 & 2.6 \\
\hline Vegetable oil & 0.5 & 0.5 & 0.5 & 1.71 & 0.5 \\
\hline Ground limestone & 8.6 & 8.6 & 8.6 & 8.6 & 8.6 \\
\hline Dicalcium phospahate & 1.7 & 1.7 & 1.7 & 1.7 & 1.7 \\
\hline Salt & 0.35 & 0.35 & 0.35 & 0.35 & 0.35 \\
\hline DL-Methionine & 0.28 & 0.28 & 0.29 & 0.30 & 0.28 \\
\hline L-Lysine & 0.15 & 0.15 & 0.21 & 0.24 & 0.15 \\
\hline Antioxidant & 0.05 & 0.05 & 0.05 & 0.05 & 0.05 \\
\hline Vitamin premix $^{*}$ & 0.1 & 0.1 & 0.1 & 0.1 & 0.1 \\
\hline Mineral premix ${ }^{* *}$ & 0.1 & 0.1 & 0.1 & 0.1 & 0.1 \\
\hline Salmonella inhibitor & 0.2 & 0.2 & 0.2 & 0.2 & 0.2 \\
\hline Sepiolite & 0 & 0 & 1.5 & 3.0 & 0 \\
\hline MOS & 0 & 0 & 0 & 0 & 0.1 \\
\hline Total & 100 & 100 & 100 & 100 & 100 \\
\hline Crude protein $(\%)$ & 16.0 & 16.0 & 16.0 & 16.0 & 16.0 \\
\hline $\mathrm{ME}(\mathrm{kcal} / \mathrm{kg})$ & 2779 & 2753 & 2745 & 2712 & 2770 \\
\hline Dry matter $(\%)$ & 88.43 & 88.43 & 88.60 & 88.73 & 88.44 \\
\hline Crude cellulose $(\%)^{1}$ & 2.76 & 2.70 & 2.69 & 2.64 & 2.75 \\
\hline Crude ash $(\%)$ & 12.36 & 12.32 & 12.40 & 12.31 & 12.35 \\
\hline Ether extract (\%) & 3.17 & 3.17 & 3.83 & 4.49 & 3.18 \\
\hline $\mathrm{Ca}(\%)^{1}$ & 3.70 & 3.70 & 3.70 & 3.70 & 3.70 \\
\hline Available P $(\%)^{1}$ & 0.40 & 0.40 & 0.40 & 0.40 & 0.40 \\
\hline Methionine $(\%)^{1}$ & 0.51 & 0.51 & 0.52 & 0.52 & 0.51 \\
\hline Methionine+cystine $(\%)^{1}$ & 0.78 & 0.78 & 0.78 & 0.78 & 0.78 \\
\hline Lysine $(\%)^{1}$ & 0.75 & 0.75 & 0.75 & 0.75 & 0.75 \\
\hline Tryptophan $(\%)^{1}$ & 0.17 & 0.17 & 0.17 & 0.17 & 0.17 \\
\hline
\end{tabular}

* Each kg of vitamin premix contains $15000000 \mathrm{IU} \mathrm{A}, 5000000 \mathrm{IU} \mathrm{D}_{3}, 50000 \mathrm{mg} \mathrm{E}, 10000 \mathrm{mg} \mathrm{K}{ }_{3}, 4000 \mathrm{mg} \mathrm{B}{ }_{1}, 8000 \mathrm{mg} \mathrm{B}, 5$ $000 \mathrm{mg} \mathrm{B}_{6}, 25 \mathrm{mg} \mathrm{B}_{12}, 50000 \mathrm{mg}$ niacin, $20000 \mathrm{mg}$ pentatonic acid, $2000 \mathrm{mg}$ folic acid, $250 \mathrm{mg}$ biotin, $75000 \mathrm{mg}$ ascorbic acid, $175000 \mathrm{mg}$ colin.

** Each kg of mineral premix contains $35000 \mathrm{mg} \mathrm{Mg}, 56000 \mathrm{mg} \mathrm{Mn}, 140000 \mathrm{mg} \mathrm{Zn,} 56000 \mathrm{mg} \mathrm{Fe}, 10500$ mg Cu, $1050 \mathrm{mg} \mathrm{I,}$ $280 \mathrm{mg} \mathrm{Co}, 280 \mathrm{mg} \mathrm{Se}, 700 \mathrm{mg}$ Mo.

1 Calculated values.

Feeds were formulated according to NRC requirements (13). Experimental diets were mash form and obtained using a cracker-mixer machine of $300 \mathrm{~kg}$ /hour capacity. Sugar and starch content of the diets was analyzed in accordance with AOAC standards (1). Metabolic energy was calculated according to the report by Vogt (23). The components and chemical composition of the experimental diets are given in Table 3.

Performance parameters: Live weight of the hens was measured individually at the beginning and at the end of the experiment. Mortality, egg production and number of broken eggs in the groups were recorded daily. In the laying period, feed intake was measured every 15 days, and eggs were weighed every other day. Egg production was expressed as \%/hen/day. In addition, egg mass was calculated from egg weight and egg production, and feed conversion ratio was determined from egg mass and feed intake values.
Egg quality parameters: From the beginning of the experiment, 24 eggs from each treatment group were collected once in every 4 weeks, and their shape index, shell thickness, shell break resistance, albumen height, Haugh unit, RYCF (Roche yolk colour fan) value, L (brightness), a (redness) and b (yellowness) values were determined 24 hours after collection. At the end of the experiment, 6 eggs from each group were analyzed for aflatoxin B1 and total aflatoxin (B1+B2+G1+G2) content (2). Shape index was calculated by a tool determining the egg's width to length ratio. Shell thickness was calculated as the mean of measurements (by a Mitutoyo digital micrometer) taken after peeling off the membrane of the pointed, blunt and middle part.) Break resistance was measured by a Newton type Futura resistance meter. White height was measured electronically by Futura white and yellow height measuring unit. Haugh unit was calculated using albumen height and egg weight values 
by Futura egg quality analyis program (8) using the following formula:

Haugh unit $=100 \log$ (Albumen height $+7.57-1.7$ Egg weight $^{0.37}$ )

Values regarding egg yolk were determined by CR10 Konica Minolta Colour Reader.

Blood analysis: At the end of the experiment, blood samples were taken from 10 hens per group, and total serum protein, albumin, bilirubin, total cholesterol, $\mathrm{Ca}$, ALT ve AST values were determined. Blood was taken individually from the vein under the wing, with the help of a syringe. Analyses were carried out using Roche Cobas Integra original kits by Roche Cobas Integra 800 equipment.

Digestibility: At the end of the experiment, the feces of six hens from each group were examined for $\mathrm{pH}$ value and dry matter. Dry matter ratio of feces was determined according to AOAC (1), $\mathrm{pH}$ was measured by a digital $\mathrm{pH}$ meter set for $22{ }^{\circ} \mathrm{C}$. In addition, digestibility of aflatoxin B1 and total aflatoxin were determined. For this, chromium oxide was given in $0.3 \%$ ratio to the feed of 6 hens from each group, and fed to them for three days. Feces from the last two days were collected and analyzed for chromium oxide and aflatoxin content (2). Digestibility of aflatoxin was calculated on the basis of the equation by (12):

$$
\begin{aligned}
& \text { Nutrient Indicator in feed (\%) Nutrient in feces (\%) }
\end{aligned}
$$

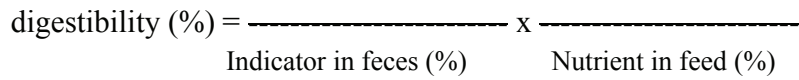

Statistical analysis: The results of all experiments were analyzed statistically using the analysis of variance procedures of the statistical program MiNiTAB 14 . Significant differences were tested further using Duncan's test (5).

\section{Results}

Performance of laying hens: No significant differences were observed in livability, live weights at the beginning and at the end of the experiment, change in live weight, egg weight and feed intake $(p>0.05)$. The effect of the feeding of hens with feed-mixture containing aflatoxin (NK) was negative on egg production, egg mass and feed conversion ratio. The addition \% 1.5 sepiolite resulted in increased egg production and egg mass compared to NK and MOS groups, and it improved feed efficiency $(p<0.05)$. The group receiving \% 1.5 sepiolite had values of these parameters similar to those of the control group $(p>0.05)$. When \% 3 sepiolite and MOS were supplemented, significant differences were not found $(p>0.05)$, although there was an improvement in feed efficiency, egg production and egg mass (Tables 4 and 5). The positive effect of sepiolite supplementation on feed efficiency had been explained as a result of decreasing viscosity of the inside of jejunum, moreover, as a results of the increasing the digestibility of organic materials by reducing the speed of passaging through the intestine $(16,17)$.

Egg quality: There were no significant differences between the groups in internal and external qualities of eggs $(p>0.05)$, such as in albumen height, haugh unit, cracked-broken eggs, shape index, shell resistance and shell thickness (Table 6). However, in NK group, the ratio of cracked-broken eggs was numerically higher and haugh unit was lower than in the other groups. In two separate experiments, \% 1.5 sepiolite supplement to the feed increased $\mathrm{Ca}$ amount in the shell (21), whereas the addition of $\% \quad 0.1$ MOS increased the proportion of cracked-broken eggs (3).

While there was no difference found between the groups in RYCF, L and b parameters of egg yolk $(p>0.05)$, value of NK was found to be numerically higher than that of the other groups (Table 7).

Analyses carried out at the end of the experiment showed no aflatoxin $\mathrm{B} 1$ and total aflatoxin $(\mathrm{B} 1+\mathrm{B} 2+\mathrm{G} 1+\mathrm{G} 2)$ in the eggs from any of the groups. Thus it seems that aflatoxin given with the feed in this experiment had not passed into the eggs.

Blood parameters: There were no significant differences $(p>0.05)$ between the test groups in their total serum protein, albumin, bilirubin, total cholesterol, calcium, phosphorus, AST and ALT values (Table 8).

Digestion: The $\mathrm{pH}$ of the faeces of hens in NK group was higher $(p<0.05)$ than that of those in the $K$ and S2 groups. The highest proportion of dry matter of the feces was found in the control group, although there was no significant difference between the groups $(\mathrm{P}>0.05)$ (Table 9).

Just about all of the aflatoxin, found in trace amount (2 ppb) in the control group, passed naturally from the digestive system through to the body. MOS and sepiolite supplementation decreased the digestibility of aflatoxin by $6-13 \%$ (Table 9 ). That is, in these groups, some of the aflatoxin received with the feed was bound and discarded with the feces. Therefore, since aflatoxin was taken up by the body in a lower quantity, its harmful effects were also less evident in these groups. It had been reported earlier that the micotoxin-binding capacity of silica minerals is determined by several factors such as chemical composition, particle size, surface acidity, toxin level. The in vitro micotoxin-binding capacity of various minerals had been reported to be between \% 86 and \% 97. However, the measurements taken under laboratory conditions had been difficult to reproduce in experiments with animals (in vivo), and the results were often not satisfactory (20). 
Table 4. Livability, live weights at the beginning and end of the experiment, and changes in live body weight.

Tablo 4.Yaşama gücü, deneme başı ve sonu canlı ağırlık ve canlı ağırlık değişimleri.

\begin{tabular}{|c|c|c|c|c|}
\hline Groups & $\begin{array}{c}\text { Livability } \\
(\%)\end{array}$ & $\begin{array}{l}\text { Body weight at the beginning } \\
\text { of the experiment } \\
\text { (g) }\end{array}$ & $\begin{array}{l}\text { Body weight at the end of } \\
\text { the experiment } \\
\text { (g) }\end{array}$ & $\begin{array}{l}\text { Changes in live } \\
\text { weight } \\
(\mathrm{g})\end{array}$ \\
\hline NK & $94.4 \pm 5.6$ & $1680 \pm 47.4$ & $1721 \pm 59.8$ & $41.1 \pm 52.6$ \\
\hline $\mathrm{K}$ & $100 \pm 0.0$ & $1678 \pm 43.0$ & $1746 \pm 55.5$ & $67.8 \pm 22.0$ \\
\hline MOS & $100 \pm 0.0$ & $1618 \pm 42.4$ & $1706 \pm 42.8$ & $87.8 \pm 19.9$ \\
\hline S1 & $94.4 \pm 5.6$ & $1642 \pm 25.8$ & $1707 \pm 24.3$ & $64.4 \pm 12.6$ \\
\hline S2 & $100 \pm 0.0$ & $1648 \pm 31.4$ & $1691 \pm 44.1$ & $43.3 \pm 41.4$ \\
\hline $\mathrm{P}$ value & 0.580 & 0.771 & 0.941 & 0.852 \\
\hline
\end{tabular}

Table 5. Performance parameters.

Tablo 5. Performans değerleri.

\begin{tabular}{lccccc}
\hline Groups & $\begin{array}{c}\text { Egg production } \\
(\% / \text { hen/day })\end{array}$ & $\begin{array}{c}\text { Feed intake } \\
(\mathrm{g} / \text { hen/day })\end{array}$ & $\begin{array}{c}\text { Egg weight } \\
(\mathrm{g} / \mathrm{egg})\end{array}$ & $\begin{array}{c}\text { Egg mass } \\
(\mathrm{g} / \text { hen/day })\end{array}$ & $\begin{array}{c}\text { Feed conversion ratio } \\
(\mathrm{g} \text { feed/g egg })\end{array}$ \\
\hline NK & $77.8 \pm 1.06^{\mathrm{b}}$ & $117.3 \pm 1.5$ & $59.7 \pm 0.82$ & $46.5 \pm 1.23^{\mathrm{b}}$ & $2.53 \pm 0.07^{\mathrm{a}}$ \\
K & $82.1 \pm 1.23^{\mathrm{ab}}$ & $114.3 \pm 1.2$ & $60.4 \pm 0.94$ & $49.6 \pm 1.46^{\mathrm{ab}}$ & $2.31 \pm 0.06^{\mathrm{bc}}$ \\
MOS & $79.6 \pm 1.03^{\mathrm{b}}$ & $117.3 \pm 2.3$ & $60.7 \pm 1.19$ & $48.3 \pm 1.03^{\mathrm{b}}$ & $2.43 \pm 0.10^{\mathrm{ab}}$ \\
S1 & $85.4 \pm 1.26^{\mathrm{a}}$ & $114.0 \pm 3.6$ & $60.9 \pm 0.46$ & $52.1 \pm 0.68^{\mathrm{a}}$ & $2.19 \pm 0.05^{\mathrm{c}}$ \\
S2 & $81.0 \pm 2.15^{\mathrm{ab}}$ & $117.0 \pm 2.1$ & $60.4 \pm 0.86$ & $48.8 \pm 0.58^{\mathrm{ab}}$ & $2.40 \pm 0.06^{\mathrm{abc}}$ \\
P value & 0.032 & 0.712 & 0.878 & 0.041 & 0.041 \\
\hline
\end{tabular}

$\overline{\mathrm{a}, \mathrm{b}, \mathrm{c}}$ Values within a column with no common superscripts differ significantly $(\mathrm{P}<0.05)$.

Table 6. Internal and external quality of eggs.

Tablo 6. Yumurta iç ve dış kalite özellikleri.

\begin{tabular}{lcccccc}
\hline Groups & $\begin{array}{c}\text { Albumen height } \\
(\mathrm{mm})\end{array}$ & Haugh unit & $\begin{array}{c}\text { Cracked-broken eggs } \\
(\%)\end{array}$ & $\begin{array}{c}\text { Shell resistance } \\
(\mathrm{N})\end{array}$ & $\begin{array}{c}\text { Shell thickness } \\
\left(10^{-2} \mathrm{~mm}\right)\end{array}$ & $\begin{array}{c}\text { Shape index } \\
\text { NK }\end{array}$ \\
$6.24 \pm 0.14$ & $76.8 \pm 0.76$ & $2.43 \pm 0.52$ & $38.3 \pm 0.91$ & $32.25 \pm 5.80$ & $78.3 \pm 0.3$ \\
K & $6.29 \pm 0.13$ & $79.1 \pm 1.20$ & $1.55 \pm 1.13$ & $39.7 \pm 0.81$ & $32.57 \pm 3.01$ & $77.8 \pm 0.3$ \\
MOS & $6.53 \pm 0.13$ & $79.7 \pm 0.92$ & $1.86 \pm 0.93$ & $38.3 \pm 0.61$ & $32.26 \pm 3.38$ & $77.2 \pm 0.4$ \\
S1 & $6.31 \pm 0.18$ & $79.4 \pm 0.99$ & $1.07 \pm 0.45$ & $39.8 \pm 0.92$ & $32.28 \pm 2.08$ & $78.5 \pm 0.3$ \\
S2 & $6.53 \pm 0.14$ & $79.5 \pm 1.17$ & $1.75 \pm 0.91$ & $40.1 \pm 0.57$ & $32.89 \pm 2.32$ & $78.6 \pm 0.3$ \\
P value & 0.152 & 0.277 & 0.522 & 0.272 & 0.645 & 0.345 \\
\hline
\end{tabular}

Table 7. Egg yolk parameters.

Tablo 7. Yumurta sarısı özellikleri.

\begin{tabular}{lcccc}
\hline Groups & RYCF & L & $\mathrm{a}$ & $\mathrm{b}$ \\
\hline NK & $12.1 \pm 0.05$ & $40.52 \pm 0.09$ & $5.30 \pm 0.18$ & $13.51 \pm 0.12$ \\
K & $12.3 \pm 0.06$ & $40.43 \pm 0.10$ & $5.72 \pm 0.08$ & $13.66 \pm 0.14$ \\
MOS & $12.2 \pm 0.06$ & $40.38 \pm 0.13$ & $5.32 \pm 0.12$ & $13.22 \pm 0.17$ \\
S1 & $12.2 \pm 0.09$ & $40.56 \pm 0.08$ & $5.31 \pm 0.11$ & $13.61 \pm 0.17$ \\
S2 & $12.3 \pm 0.09$ & $40.58 \pm 0.18$ & $5.48 \pm 0.13$ & $13.37 \pm 0.18$ \\
P value & 0.317 & 0.705 & 0.115 & 0.302 \\
\hline
\end{tabular}

Table 8. Some blood parameters.

Tablo 8. Bazı kan parametreleri.

\begin{tabular}{lcccccccc}
\hline Groups & $\begin{array}{c}\text { Total protein } \\
(\mathrm{g} / \mathrm{dL})\end{array}$ & $\begin{array}{c}\text { Albumin } \\
(\mathrm{g} / \mathrm{dL})\end{array}$ & $\begin{array}{c}\text { Bilirubin } \\
(\mathrm{mg} / \mathrm{dL})\end{array}$ & $\begin{array}{c}\text { AST } \\
(\mathrm{U} / \mathrm{L})\end{array}$ & $\begin{array}{c}\text { ALT } \\
(\mathrm{U} / \mathrm{L})\end{array}$ & $\begin{array}{c}\text { Total cholesterol } \\
(\mathrm{mg} / \mathrm{dL})\end{array}$ & $\begin{array}{c}\text { Ca } \\
(\mathrm{mg} / \mathrm{dL})\end{array}$ & $\begin{array}{c}\mathrm{P} \\
(\mathrm{mg} / \mathrm{dL})\end{array}$ \\
\hline NK & $5.7 \pm 0.2$ & $2.23 \pm 0.07$ & $0.03 \pm 0.007$ & $164 \pm 6.3$ & $1.50 \pm 0.17$ & $164 \pm 12.8$ & $33.0 \pm 2.0$ & $6.6 \pm 0.5$ \\
K & $5.5 \pm 0.1$ & $2.25 \pm 0.05$ & $0.02 \pm 0.004$ & $163 \pm 5.9$ & $1.80 \pm 0.20$ & $194 \pm 17.4$ & $36.1 \pm 2.1$ & $6.6 \pm 0.4$ \\
MOS & $5.7 \pm 0.2$ & $2.22 \pm 0.04$ & $0.03 \pm 0.007$ & $168 \pm 10.6$ & $1.89 \pm 0.31$ & $166 \pm 23.9$ & $33.9 \pm 1.5$ & $6.5 \pm 0.3$ \\
S1 & $5.6 \pm 0.2$ & $2.15 \pm 0.05$ & $0.02 \pm 0.005$ & $165 \pm 7.2$ & $1.70 \pm 0.21$ & $164 \pm 16.4$ & $34.3 \pm 1.7$ & $6.1 \pm 0.3$ \\
S2 & $5.9 \pm 0.2$ & $2.22 \pm 0.05$ & $0.04 \pm 0.006$ & $176 \pm 8.5$ & $1.80 \pm 0.42$ & $174 \pm 26.2$ & $35.1 \pm 1.9$ & $6.2 \pm 0.3$ \\
P value & 0.631 & 0.718 & 0.058 & 0.757 & 0.883 & 0.791 & 0.801 & 0.889 \\
\hline
\end{tabular}


Table 9. Some digestion features.

Tablo 9. Bazı sindirim özellikleri.

\begin{tabular}{|c|c|c|c|c|}
\hline Groups & $\begin{array}{l}\text { Faeces pH } \\
\left(22^{\circ} \mathrm{C}\right)\end{array}$ & $\begin{array}{c}\text { Faeces dry matter } \\
(\%)\end{array}$ & $\begin{array}{l}\text { Digestibility* of } \\
\text { aflatoxsin B1 } \\
(\%)\end{array}$ & $\begin{array}{c}\text { Digestibility* of total aflatoxin } \\
(\mathrm{B} 1+\mathrm{B} 2+\mathrm{G} 1+\mathrm{G} 2) \\
(\%)\end{array}$ \\
\hline NK & $8.56 \pm 0.06^{\mathrm{a}}$ & $22.37 \pm 1.30$ & 73.95 & 80.05 \\
\hline K & $7.80 \pm 0.20^{\mathrm{b}}$ & $26.33 \pm 1.20$ & 96.32 & 96.22 \\
\hline MOS & $8.05 \pm 0.18^{\mathrm{ab}}$ & $23.07 \pm 1.35$ & 67.17 & 67.71 \\
\hline $\mathrm{S} 1$ & $8.16 \pm 0.24^{\mathrm{ab}}$ & $24.27 \pm 1.42$ & 67.23 & 69.92 \\
\hline S2 & $7.82 \pm 0.17^{\mathrm{b}}$ & $26.93 \pm 0.83$ & 65.23 & 68.28 \\
\hline $\mathrm{P}$ value & 0.033 & 0.101 & & \\
\hline
\end{tabular}

\section{Discussion and Conclusion}

The results showed that MOS and sepiolite added to the feed of layers receiving aflatoxin binds to a proportion of the toxin which, in turn, is eliminated with the feces. Although the binding capacity of MOS and sepiolite to the toxin is similar, sepiolite seems to be more beneficial in restoring the production parameters of hens; moreover, it seems to have other positive effects on the metabolism as well.

The added sepiolite reduced the losses, caused by aflatoxin, in the performance of the birds. On the other hand, MOS had no significant effect on these parameters, although it also caused numerical increases in them. In order to demonstrate more clearly the effects of sepiolite on restoring egg quality, further studies with higher doses of aflatoxin and longer experiment period should be carried out.

As a result, sepiolite supplementation to laying hen diets containing aflatoxins can be concluded that had the beneficial effects on hen performance.

\section{References}

1. AOAC (1990): Official Methods of Analysis (15 ${ }^{\text {th }}$ ed.), Association of official analytical chemists, Washington, D. C.

2. AOAC International (2003): Official methods of analysis of $A O A C$ International. $17^{\text {th }}$ edition, $2^{\text {nd }}$ revision. Gaithersburg, MD, USA, Association of Analytical Communities.

3. Cabuk M., Bozkurt M, Alcicek A, Catlı AU, Baser KHC (2006): Effect of a dietary essential oil mixture on performance of laying hens in the summer season. South Afr Anim Sci, 36, 215-221.

4. Dawson KA, Evans J, Kudupoje M (2001): Understanding the adsorption characteristics of yeast cell wall preparations associated with mycotoxin binding. In: Science and Technology in the Feed Industry, Lyons, T.P. and K.A. Jacques (Eds.). Nottingham University Press, Nottingham, U.K., 169-181.

5. Duncan DB (1955): Multiple Range and Multiple F Tests, Biometrics, 11, 1-42.
6. Ergul M (2000): Feed harmful and effects. Proceedings of the International Animal Nutrition Congress, September 46, Isparta, Turkey.

7. Fernando AES (2004): La Sepiolite: A special clay in the field of food to animal,

http://www.racve.es/actividades/zootecnia/2004-04-14

FernandoEscribanoSaez.htm

8. Haugh RR (1937): The Haugh Unit for measuring egg quality. U. S. Egg Poultry Magazine, 43, 522-555, 572573.

9. Huwig A, Freimund S, Kappeli O, Dutler H (2001): Mycotoxin detoxication of animal feed by different adsorbents. Toxicol Lett, 122, 179-188.

10. Kara M, Sabah E, Yuzer H, Celik MS (1998): Sepiolite as an adsorbent for elimination of mine wastes. Proceedings of the 5th International Symposium on Environmental Issues and Waste Management in Energy and Mineral Production, May 18-20, Ankara, Turkey, 717721.

11. Kubena LF, Harvey RB, Phillip TD, Clement BA (1993): Effect of hydrated sodium calcium aluminosilicate on aflatoxicosis in broiler chicks. Poult Sci, 72, 651-657.

12. Maynard LA, Loosli, JK (1969): Animal Nutrition. 5th Edn., Mc Graw-Hill Co., New York, 533.

13. NRC (1994): Nutrient Requirements of Poultry. NRC, Washington, D. C, USA

14. Oguz H, Kurtoglu V (2000): Effect of clinoptilolite on fattening performance of broiler chickens during experimental aflatoxicosis. Br Poult Sci, 41, 512-517.

15. Oguz H, Kurtoglu V, Ortatatli M (2001): Preventive efficiency of dietary zeolite (clinoptilolite) in broiler chickens during aflatoxicosis. Proceedings XV European Symposium on the Quality of Poultry Meat, September 912, Kusadasi-Turkey, 145-150.

16. Ouhida I, Perez JF, Gasa J, Puchal F (2000a): Enzymes ( $\beta$-glucanase and arabinoxylanase) and/or sepiolite supplementation and the nutritive value of maize-barleywhet based diets for broiler chickens. Br Poult Sci, 41: 617-624.

17. Ouhida I, Perez J F, Piedrafita J, Gasal J (2000b): The effects of sepiolite in broiler chicken diets of high, medium and low viscosity. Productive performance and nutritive value. Anim Feed Sci Tech 85, 183-194. 
18. Rajua MVLN, Devegowda G (2000): Influence of esterified-glucomannan on performance and organ morphology, serum biochemistry and haematology in broilers exposed to individual and combined mycotoxicosis (aflatoxin, ochratoxin and T-2 toxin). Br Poult Sci, 41, 640-650.

19. Sabah E, Celik MS (1999): Sepiolite: Characteristics and using areas. Proceedings of the $3^{\text {rd }}$ Industrial Ingredients Symposium, October 14-15, Izmir, Turkey.

20. Taylor D (2000): Mycotoxin Binders: What they are and how they work. Proceedings of the $1^{\text {st }}$ Annual OIL-DRI Animal Health Technical Symposium, August 25, Montreal, Canada.

21. Tortuero F, Rioperez L, Martin L (1993): Effect of dietary sepiolite supplementation on the performance, egg composition and mineral metabolism in laying hens. Arch Zootec, 42, 347-360.
22. Trevor KS, Macdonald EJ, Haladi S (2001): Current Concepts in Feed-Borne Mycotoxin and the Potential for Dietary Prevention of Mycotoxicoses. In: Science and Technology in the Feed Industry, Lyons, T.P. and K.A. Jacques (Eds.). Nottingham University Press, Nottingham, UK.

23. Vogt H (1984): Kraftfutter 68; 327-328. In; Close S W, Menke K H (1986): Selected Topics in Animal Nutrition. 170+A 85. Wielinger Straße 52, D-8133, feldafins.

Geliş tarihi: 20.12.2012 / Kabul tarihi: 10.10.2013
Address for correspondence:
Cengizhan MIZRAK
Poultry Research Station, Ankara, Turkey
e-mail: cengizhanmizrak@hotmail.com 